nomena in the unstable static conditions of the outer layers of the sun.

I am not aware that such a suggestion as this has ever been made to account for Sporer's law. Of course I see many objections to it. The improbability of such waves long retaining their shape, and the observed absence of sun spots in the north hemisphere from 1672 to 1704, suggest themselves as obstacles.

J. A. UDDEN

ROCK ISLAND, ILL.

\section{AFRICAN BASKETRY WEAVES}

A LARGE collection of ethnological specimens recently received by the Museum of Natural History, New York city, contains a selected series of baskets from the Barotse and Bechuana tribes. These baskets compare favorably in technique and finish with those of California and, what is of special interest, present all the typical weaves known in America. Among the Barotse baskets alone we find the following kinds of woven basketry: wicker, checker, twill, wrapped, plain twine, open twine, twilled twine, and the California 'ti.' Also in coiled basketry, one rod coil, grass coil closely covered, also with foundation showing bifurcated coil closely covered, also with only lines of stitching and coil without foundation.

The more elaborate manipulation of warp elements or materials in general, seems not to be practised, for there are neither cross-warp checkers nor cross-warp twines in the collection. The edges, while of all types, represent rather the refined variations. The thought of solidity or stability seems to have been the main idea. This is particularly well illustrated in the large rope coil and one-rod foundation coil chests and storage baskets. The technic is perfect and with the close-fitting lids give exceptional protection to grain or other contents. Strengthening by bands of the ' $t i$ ' weave, a technic heretofore thought to be limited to the Pomo Indians of California, is found; also an unusual wrapped twine, with the horizontal warp on the outside, like some Aleutian burden baskets.

The decorations in color occur chiefly in coil baskets. The color of the designs is uniformly black.
The main point of interest is that within a definite ethnic area of South Central Africa an aboriginal people practise basketry in which are found practically all of the typical weaves known to the world.

Mary Lois Kisseld

american Museum of Natural History, New York City

THE RECUPERATIVE POWER OF ITALIAN AND ENGLISH WORKMEN

To the EDitor of ScIEnce: I am afraid that the statements contained in the letter of Mr. Joseph Y. Bergen, ${ }^{1}$ as to the recuperative power of Italian and English workmen may induce some readers to unwarranted generalizations.

A statement of the kind would have more value if a comparison were made between the diet and the conditions of people of the same race and the same locality, provided in each case there existed a sufficiency of the articles of diet.

On the other hand, it is a known fact, that, generally speaking, the rural population of Europe has better recuperative powers than the inhabitants of the cities, although the latter eat much meat, while the country people live almost exclusively on a vegetable diet, meat being considered too expensive.

\section{H. BaEkeland}

\section{SPECIAL ARTICLES}

SOME LATENT CHARACTERS OF A WHITE BEAN ${ }^{2}$

IN order to secure material to display as simple illustrations of Mendel's laws of dominance and gametic purity, I made reciprocal crosses last year (1904) among four different varieties of the common bush bean. These varieties were the 'Prolific black wax,' with purple-black seeds, the 'Ne plus ultra' with yellow-brown seeds, the 'Long yellow sixweeks' with seeds of a light greenish-yellow color, and the 'White flageolet,' whose seedcoats are wholly without pigment, being transparent when saturated with liquids, but nearly white because of the inclusion of air when dry.

\footnotetext{
1 Science, May 3, 1907, page 709.

${ }^{2}$ Read before the Botanical Society of America, at New Orleans, December, 1905.
} 